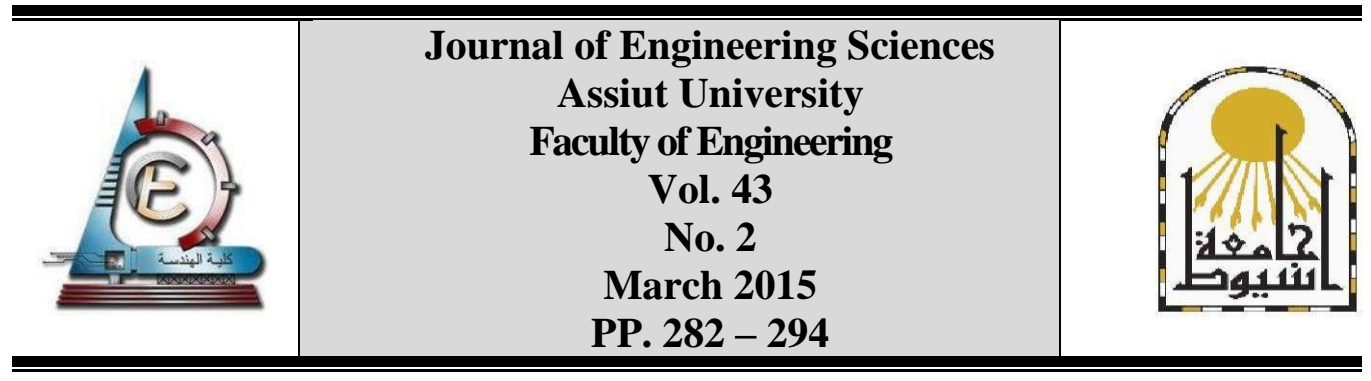

\title{
TEACHING WITH INFLUENCE: AN ANALYSIS OF TEACHING METHODS USED AT THE COURSE OF CONTROL SYSTEMS IN BUILDINGS
}

\author{
Laila M. Khodeir \\ Faculty of Engineering, Cairo, Egypt
}

(Received 1 February 2015; Accepted 5 March 2015)

\begin{abstract}
The course of the control systems in buildings was an elective course offered to junior students in credit-hour system at Ain Shams University in Egypt .The course aimed at providing students, who are not energy experts, with a tool that enables them to use energy consequences in designing sustainable buildings, in addition to enhancing critical thinking. To fulfill the course objective, a group of non-systematic teaching methods were applied. Thus the main goal of this paper is examining the application of a group of methods, in environmental design education, to promote critical thinking, to go beyond the limits of academic teaching and to influence students while creating an effective learning environment. This approach is fulfilled through the analysis of the course entitled: "Control Systems in Buildings", where different teaching methods, techniques and tools were adopted, including debate, case studies analysis, mind mapping, teamwork and various decision-making techniques. The main challenge was that these students were not architecture specialists, as their curriculum concentrates on other issues including civil works and management, in addition to environmental courses. The paper conducted analyses of the case study of the course, where the tasks performed by students, together with an evaluation of their satisfaction with the course and its overall impact on their environmental awareness, choices and exam results were analyzed. The results of this analysis, though very beneficial to any instructor working in the field of environmental education, should be limited to elective courses including a small number of students, to be fully beneficial.
\end{abstract}

Keywords: Teaching methods, Learning Environment, Sustainable Design

\section{Introduction}

This research examines the introduction of a group of non-systematic teaching methods, techniques and tools to environmental design education. It aims at verifying whether there is a significant relationship between the student's dominant learning styles and both their results and the satisfaction obtained from the usability of the professor's teaching methods and strategies in lectures, sections, or other practical activities. The paper suggests that the process of adapting the teaching style of the professor to the learning style of the students will lead to a stable rise in the academic performance. This adaptation process therefore creates "an influence" on the student's pattern of thinking. 
The course of the environmental control systems in buildings (C.S.) is an elective course offered to junior students in credit-hour system. The course aimed at providing students, who were not energy experts, with a tool that enabled them to use energy consequences in designing sustainable buildings and enhancing critical thinking. This course comprised a three -hour lecture and two hours for practical work per week. Throughout the (C.S.) course, different teaching methods, strategies and tools were adopted, including debate, case studies analysis, mind mapping, team work and various decision-making techniques. The students involved in this course were not architecture specialists, as their curriculum concentrates on other issues including civil works and management, in addition to environmental courses. The process of creating the required "influence" on their pattern of thinking formed a big challenge.

\subsection{Problem definition}

The main problem tackled through this paper is teaching an architecture-oriented course to non-architects. The experience of teaching to senior civil-background students was challenging in many ways. First, those students have spent four successive years learning civil-oriented courses (e.g. concrete and steel design) and where mainly asked to perform calculations of different structural elements. Secondly, they have not had any introductory courses that target the importance of aesthetics in designing environmental control systems, appreciating vernacular architectural forms and passive design principles. Finally these students had to acquire a number of intended learning outcomes that had to do with architecture-related skills.

\subsection{Hypothesis}

Teaching environmental control systems to students who are not purely architecture specialists without adopting a group of strategies that include the integrity between both theoretical and practical aspects would create a monotonous learning environment. This will, in turn, lead to a low-efficient learning experience. Students in such poor learning environment do not make good use of the knowledge and data extracted from environmental courses into their practical work and projects. In other words, as long as the students are not "influenced" by the knowledge they had in environmental courses, they will not be able to think critically or make full use of it.

In addition, this paper assumes that the same acquired Intended Learning Outcomes will produce more influenced students when the adopted teaching methods are characterized by:

1- Being persistent in the memory

2- Intensifying the interest

3- Creating an impulse about the course

4- Being relevant to the course content and the ILOs.

\subsection{The main purpose}

The main goal of this paper is examining the application of a group of methods, strategies and tools, in environmental design education, to promote critical thinking, to go beyond the limits of academic teaching and to influence students while creating an effective learning environment. The work presented in this paper is an attempt to design a learning environment to teach (C.S.) in buildings to students who are not purely architects. 


\section{Critical thinking and educational systems}

Upon setting efficient educational systems, the process of increasing and improving critical thinking of learners is emphasized through the integration of the concepts of critical thinking in the curriculum [1].

Critical thinking is defined as "purposeful thinking in which individuals systematically and habitually impose criteria and intellectual standards upon their thought" [2]. "It constantly reevaluates, self-corrects, and strives to improve" [3]. It is also described as a "way of right thinking" [4] and as involvement, logical decision making and taking responsibility for what we do [5]. Critical thinking is considered to belong to a higher cognitive level of Bloom's cognitive objective taxonomy. A new version is illustrated in figure (1), which involves analysis, evaluation, synthesis and creation [6], [7]. Thus critical thinking includes both high cognitive skills and sufficient desire for development and application [8].

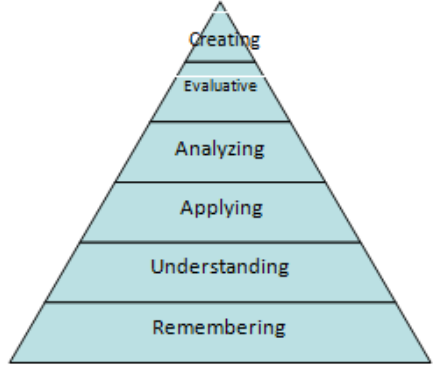

Fig. 1. Bloom's Taxonomy (new version) [7]

\subsection{Educational methods and teaching techniques}

Generally, educational methods are divided into two main groups. The first group is "student-oriented" while the second is "teacher oriented". Although the two groups are different, they both involve the application of common methods, like "narrating lecture," "discussion", "asking questions", "sample case", "showing sample", "problem solving". Teaching techniques are classified into several techniques, including "brain-storming", "question and answer", "mimesis", "pair and group works", "role-playing" and "creative drama". On the other hand, educational environment is divided into two main categories: "distance education" and "formal education." Educational tools vary from traditional to digital tools [9].

Nevertheless, the choice between the previously discussed teaching methods varies according to a number of factors. These factors include: the course content, characteristics of students, characteristics of the instructor and characteristics of the educational tools [9].

\subsection{Environmental design education in the context of creative thinking}

Environmental design education mainly includes theoretical lectures that are based on the transfer of information and evaluation. When merging the environmental design education in the context of creative thinking, the nature of such type of education adapts to include creative workshop activities. While theoretical lectures are teacher-oriented, the workshops include both teacher-oriented and student-oriented educational methods.

Table 1 identifies the general set-up for conducting the course of (C.S.) in buildings. 


\section{Table 1.}

The general set-up for conducting the course of C.S.in buildings. Source: Author

\begin{tabular}{|c|c|c|}
\hline Factors & Details & \\
\hline Course Content & \multicolumn{2}{|c|}{$\begin{array}{l}\text { Includes most of the passive and hybrid environmental control systems } \\
\text { and some active environmental control systems in buildings. }\end{array}$} \\
\hline \multirow{4}{*}{$\begin{array}{l}\text { Characteristics of } \\
\text { students }\end{array}$} & Age of students & 21-22 years \\
\hline & Sex & Both males and females \\
\hline & Field of profession & Environmental engineering \\
\hline & average no. of attending students & $20-30$ student \\
\hline $\begin{array}{l}\text { Characteristics of the } \\
\text { instructor }\end{array}$ & Qualifications & $\begin{array}{l}\text { Master degree in environmental } \\
\text { buildings, several published } \\
\text { papers in Environmental issues. } \\
\text { PHD in Facility Management. }\end{array}$ \\
\hline \multirow{2}{*}{$\begin{array}{l}\text { Characteristics of } \\
\text { the educational tools }\end{array}$} & Formal education & Classroom, workshop \\
\hline & Remote education & $\begin{array}{l}\text { Online group for remote } \\
\text { education }\end{array}$ \\
\hline
\end{tabular}

\section{Methodology}

The population for this experiment includes all the students who attended the environmental control systems in buildings course, which forms 23 students. The data collection and analysis involved three main tools. The first is a small questionnaire to assess the students' reactions and the degree of influence of the course on them. Then, analysis of the assignments was applied, where the output of the students was analysed in order to trace the impact the course had on them; the influence was traced through analysing the quality of samples of the work submitted by the students in both individual work and group work. Finally, a comparative analysis was held between the final exam grades of the 2013 fall semester students and the final exam grades of the 2011 fall students.

\section{The case study}

The course of (C.S) in buildings is an elective course in the new programs of credithour system in the Faculty of Engineering, Ain Shams University. The course is a graduate-level course that is offered to students in their final year. It includes 75 credit hours and its target group is engineering students who are not purely architects as they study architecture courses as electives and apply the obtained knowledge from such courses on a comprehensive project that extends throughout the whole final year.

Table (2) shows the different attributes of the applied methodology of this paper and their relationship with the overall objective of the paper.

\subsection{Class background}

The class consisted of a mixture of lectures, in-class exercises, assigned sections, team projects, presentations, discussions and an examination. The students were encouraged to take active control of their learning, express and support their ideas, make predictions and 
hypotheses and test them by different evidences extracted from research work. They worked both individually and in small groups and presented their work to the classroom for debate. Students were to make their ideas overt, to compare them with those of other students and to give explanations. Emphasis was also placed on giving the students the opportunity to use graphical methods including mind maps, checklists and charts.

\section{Table 2.}

The attributes of the applied methodology. Source: Author

\begin{tabular}{|c|c|c|c|}
\hline Stages of implementation & $\begin{array}{l}\text { Tools and techniques } \\
\text { applied for data } \\
\text { collection and analysis }\end{array}$ & Assessed attributes & $\begin{array}{l}\text { General } \\
\text { Objective }\end{array}$ \\
\hline $\begin{array}{l}\text { 1. Assessing results of } \\
\text { final exam }\end{array}$ & Comparative analysis & $\begin{array}{l}\text { The performance of } \\
\text { students in exam compared } \\
\text { to other students in the } \\
\text { same course. }\end{array}$ & \multirow{4}{*}{ 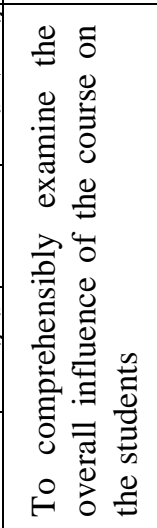 } \\
\hline Stages of implementation & $\begin{array}{l}\text { Tools and techniques } \\
\text { applied for data } \\
\text { collection and analysis }\end{array}$ & Assessed attributes & \\
\hline $\begin{array}{l}\text { 2. Assessing the end } \\
\text { results of students. }\end{array}$ & $\begin{array}{l}\text { Analyses of assignments } \\
\text { and the output work of } \\
\text { students. }\end{array}$ & $\begin{array}{l}\text { The influence of the course } \\
\text { on the quality and depth of } \\
\text { the end products. }\end{array}$ & \\
\hline $\begin{array}{l}\text { 3. Assessing the reactions } \\
\text { of students towards the } \\
\text { course }\end{array}$ & Questionnaire & $\begin{array}{l}\text { The real opinions of the } \\
\text { students about the degree of } \\
\text { influence of the course. }\end{array}$ & \\
\hline
\end{tabular}

\subsection{Teaching method of the course}

The main four elements of the educational experience adopted in the C.S. course, including educational method, teaching techniques, educational environment and educational tools, are illustrated in figure (2).

The teaching methods adopted in this course involved the use of a number of tools. Table (3) shows a brief description of each tool and the field of its application relative to the course content.

Table 3.

Tools adopted in C.S. course. Source: Author

\begin{tabular}{|l|l|}
\hline Tool & Field of application \\
\hline Mind maps & $\begin{array}{l}\text { In setting a strategy for the selection of the cooling and ventilating system } \\
\text { for different types of buildings. }\end{array}$ \\
\hline Checklists & $\begin{array}{l}\text { In analyzing the different environmental control systems existing in real- } \\
\text { life case studies }\end{array}$ \\
\hline videos & $\begin{array}{l}\text { In illustrating different features of environmental control systems in } \\
\text { buildings and other related issues, showing the convertible, movable and } \\
\text { adaptable buildings. }\end{array}$ \\
\hline Charts & In comparing different passive heating/cooling strategies. \\
\hline Team work & $\begin{array}{l}\text { In setting a strategy for cooling systems selection and in analysis of wind } \\
\text { movement in the students' own apartments. }\end{array}$ \\
\hline $\begin{array}{l}\text { Simulating wind } \\
\text { movement }\end{array}$ & $\begin{array}{l}\text { In each student's own apartment, to analyze the efficiency of natural } \\
\text { ventilation and add solutions for improvement. }\end{array}$ \\
\hline
\end{tabular}




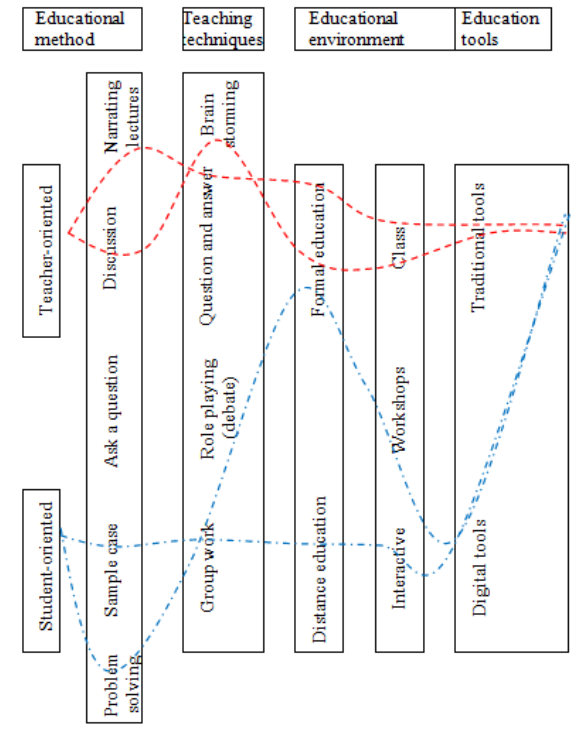

Fig. 2. The components of the educational experience in the C.S. course. Source: Author

\subsection{Strategy of the evaluation of course students}

The analysis of the case study course included the evaluation of the students' reactions towards the applied tools and teaching methods. Students were asked to describe the type of influence they had as a result of each tool or method applied in the course. Types of influences were classified into a number of descriptive classes, including: being persistent in memory, intensifying interest about the topics discussed and creating impulse about the content of the course. Students were also asked to determine how relevant the adopted teaching methods were to both the course content and its intended learning outcomes.

The students were asked to give a ranking to the tools applied in this course as follows: 1 (very much beneficial/relevant), 2 (much beneficial/relevant), 3 (neutral), 4 (less beneficial/ relevant) and 5 (very less beneficial/relevant). Finally the students were asked two structured questions that reflect their overall reactions towards the course as follows:

In Question (1), the students were required to specify the effect the course had on their way of evaluating passive design methods in general and how they valued sustainable design, as most of them at the beginning of the course thought that passive design strategies were useless and did not appreciate their value and impact.

The second question was intended to trace the effect of the course on the students' final design projects, regarding a number of aspects as follows:

- Including passive design strategies in the early design phase of the final project.

- The degree of reliance on passive strategies in their final project.

- The Integration of passive design strategies with active design strategies in their final projects.

- The application of the generated checklists, mind map and simulations in the C.S. course on their design project.

- The ease of determining the dimensions and spaces needed for each passive strategy adopted in the project. 


\section{Results}

The results of this study are discussed in terms of the previously discussed methodology, starting with assessing both the results of the final exam and the end results of the students. This assessment is considered as a primary indicator to the existence of an influence on the students, and not as a measuring tool. Finally, an assessment of the reactions of students towards the course was performed. This included measuring the agreed effect of each teaching method on the students and the relevancy between these methods and the intended learning outcomes of the course.

\subsection{Assessing results of final exam}

Compared to the students who had the same course in the fall 2011 semester, it is obvious that the level of students' grades has risen, as shown in figure (3).

\subsection{Assessing the end results of students}

Upon assessing the end product of the students, some issues were discussed, including interest about the course, desire in performing deep research on topics relevant to the course content, quality of work submitted and creative thinking abilities.

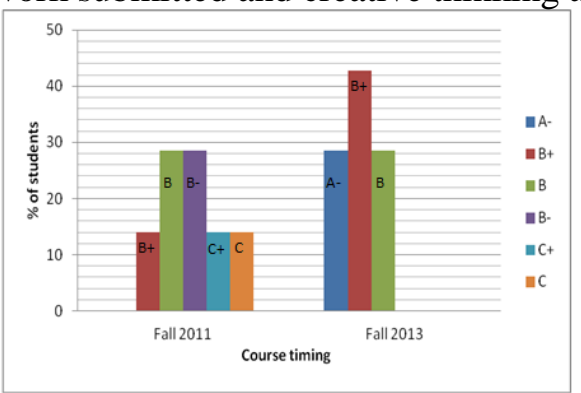

Fig. 3. Comparing the performance of the students in two different semesters.

\subsubsection{Interest about the course}

The students showed great interest in presenting the tasks required from them, whether in individual work or in group work. Figure (4) shows a sample of the students' work, as they were asked to show the wind movement in their own apartments through $2 \mathrm{D}$ drawings. Some of the students presented their work in 3D form, simulating the real wind movement, figure (5). They even added some interior shots showing the impact of adding treatments to the interior walls (figure 6).

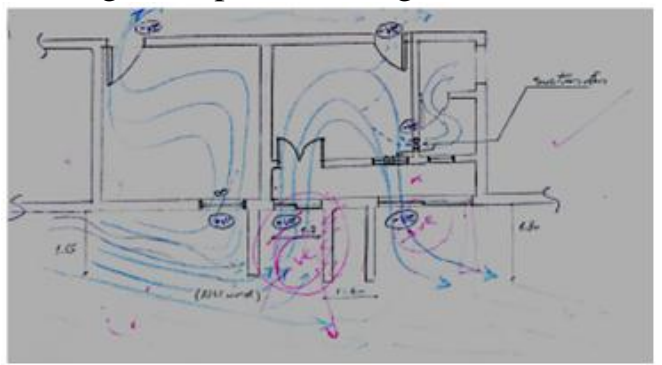

Fig. 4. The original requirements in $2 \mathrm{~d}$ form

\subsubsection{Desire in deep research}

Some of the students' work reflected their increased interest in making deep research on topics related to the course content. Figure (7) shows an analysis performed by one of the students to the real wind movement in the zone of his apartment. 

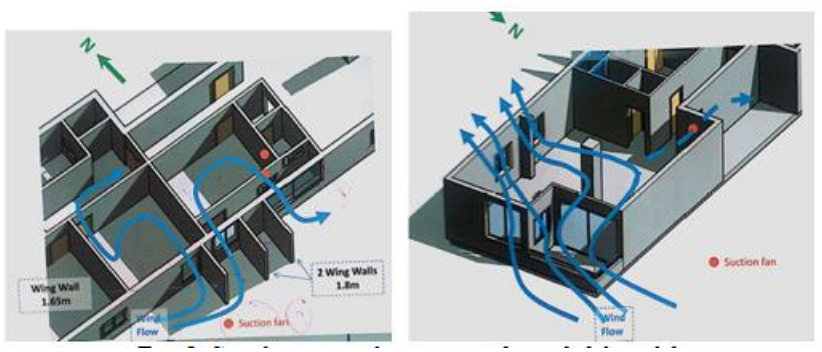

Fig. 5. Simulating wind movement through $3 \mathrm{~d}$ models
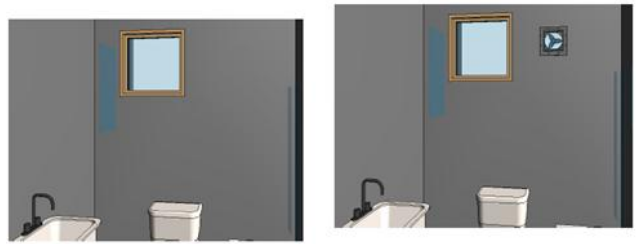

Fig. 6. adding interior $3 d$ shots for suggested treatments
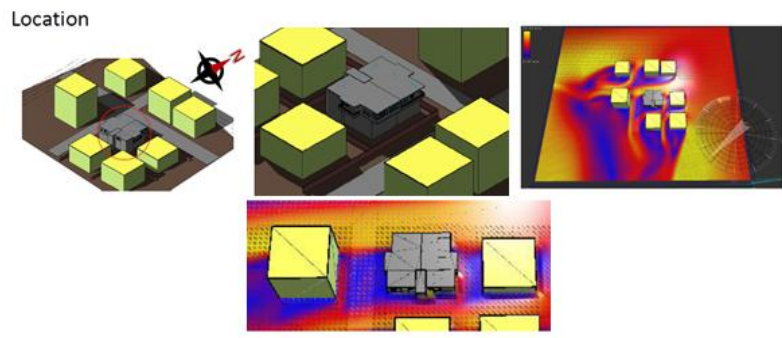

Fig. 7. Deep analysis of the real prevailing wind direction
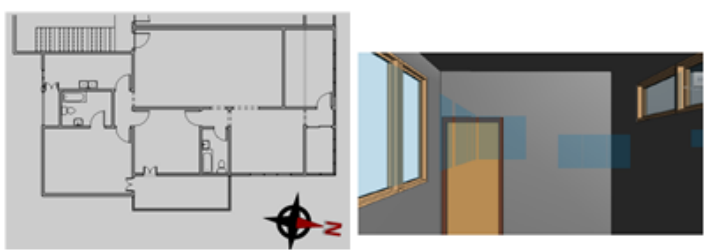

Fig. 8. Quality of presented work by the course students

\subsubsection{Quality of submitted work}

The end product of most of the course students was always presented with a high quality of presentation techniques and using efficient graphics and good visual design. The students, though not purely architects, submitted their drawings in full detail (Figure 8).

\subsubsection{Creative thinking abilities}

Students at this course showed creative thinking in different assignments that demanded the design of shading devices, enhancing natural wind movement through space and setting a selection of strategies for different passive, hybrid and active control systems. Figure 9 shows a mind map generated by the course students in class, where they designed the map to help designers choose from among different types of passive systems. In other words, they made a design-making tool based on concepts discussed in the course. They also generated a checklist that aimed at getting a preliminary review on the applied passive methods in different types of buildings. The checklist included most of the features that should exist in a building to be categorized as passive (Figure 10).The feasibility of this list was examined by the students on real buildings. 


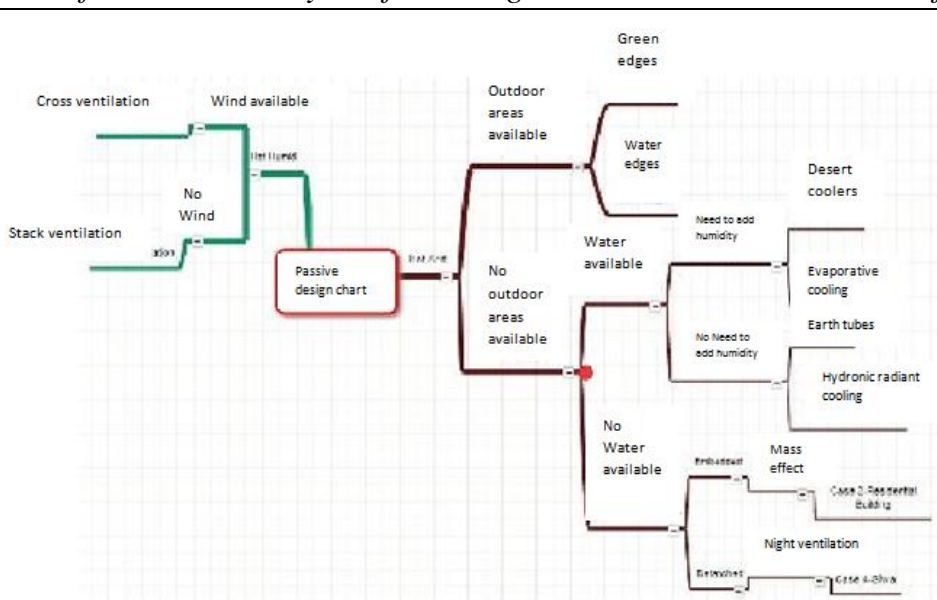

Fig. 9. Sample mind-map generated by students as a decision-making tool

\subsection{Assessing the reactions of students}

It is worth mentioning that when the course students were asked to participate in the course evaluation, they all attended willingly, although this evaluation was done three months after the end of the course.

\begin{tabular}{|c|c|c|c|}
\hline \multicolumn{4}{|l|}{ Used Strategies } \\
\hline Main Category & $\begin{array}{l}\text { Sub } \\
\text { Category }\end{array}$ & \multicolumn{2}{|c|}{ Sub-Sub Category } \\
\hline \multirow[t]{9}{*}{ Heat Prevention Gain } & \multirow[t]{2}{*}{ Shading } & \multicolumn{2}{|c|}{$\checkmark$ Building Component } \\
\hline & & \multicolumn{2}{|c|}{$\begin{array}{l}\text { Shading Element } \\
\text { (hz. vert. compound roof) }\end{array}$} \\
\hline & \multirow{7}{*}{ Envelope } & \multicolumn{2}{|c|}{$\checkmark$ Cavity wall } \\
\hline & & \multicolumn{2}{|c|}{$\checkmark$ Double roof } \\
\hline & & \multicolumn{2}{|c|}{ Insulating membrane structure } \\
\hline & & \multicolumn{2}{|c|}{ Green roof } \\
\hline & & \multicolumn{2}{|c|}{$\checkmark$ Soil sink } \\
\hline & & \multicolumn{2}{|c|}{ Active earth insulation } \\
\hline & & \multicolumn{2}{|c|}{ Glazing Material } \\
\hline \multirow[t]{6}{*}{ Evaporative cooling } & Passive & \multicolumn{2}{|c|}{$\checkmark$ Green Edges } \\
\hline & & \multicolumn{2}{|c|}{ Water Edges } \\
\hline & Hybrid & \multicolumn{2}{|c|}{ Desert Cooler } \\
\hline & & \multicolumn{2}{|c|}{ Earth tube heat exchanger } \\
\hline & & \multicolumn{2}{|c|}{ Hydronic radiant cooling } \\
\hline & Active & \multicolumn{2}{|c|}{ Evaporative cooling towers } \\
\hline \multirow{3}{*}{\multicolumn{2}{|c|}{ Passive Cooling (Ventilative) }} & \multicolumn{2}{|c|}{$\checkmark$ Cross Ventilation } \\
\hline & & \multicolumn{2}{|c|}{$\checkmark$ Stack Effect } \\
\hline & & \multicolumn{2}{|c|}{ Combined } \\
\hline \multirow{4}{*}{\multicolumn{2}{|c|}{ Passive Cooling (Radiative) }} & Direct & Mass Effect \\
\hline & & \multirow[t]{3}{*}{ Indirect } & Movable Roof Insulation \\
\hline & & & Water Filled Plastic Bags \\
\hline & & & Roof Radiant Material \\
\hline
\end{tabular}


JES, Assiut University, Faculty of Engineering, Vol. 43, No. 2, March 2015, pp. $282-294$

\begin{tabular}{|l|l|l|}
\hline Used Strategies & \multicolumn{2}{|l|}{} \\
\hline Passive Solar Heating & Direct & Solar collector \\
\cline { 2 - 3 } & \multirow{4}{*}{ Indirect } & Storing mass (Trombe wall)/(Water wall) \\
\cline { 2 - 3 } & & Roof pond \\
\cline { 2 - 3 } & Isolated & Sun space \\
\cline { 2 - 2 } & & Thermosiphon \\
\hline \multirow{5}{*}{ Daylighting } & \multicolumn{2}{|c|}{$\checkmark$ Windows } \\
\cline { 2 - 3 } & Skylights \\
\cline { 2 - 3 } & \multicolumn{2}{|c|}{$\checkmark$ Clerestory Windows } \\
\cline { 2 - 3 } & Sawtooth \\
\cline { 2 - 3 } & Atria \\
\cline { 2 - 3 } & Light Tubes \\
\cline { 2 - 3 } & Light Shelves \\
\hline
\end{tabular}

Fig. 10. Sample checklist generated by the students to help classify Passive Buildings

Table (4) shows the results of the evaluation of students' reactions to different methods adopted in the course of control systems.

Table 4.

The evaluation results of students' reactions

\begin{tabular}{|l|l|l|l|}
\hline $\begin{array}{l}\text { M1. The use of debates in this } \\
\text { course }\end{array}$ & $\begin{array}{l}\% \text { of students } \\
\text { agreeing }\end{array}$ & $\begin{array}{l}\text { M2. The benefits of self- } \\
\text { learning presentations }\end{array}$ & $\begin{array}{l}\% \text { of } \\
\text { students } \\
\text { agreeing }\end{array}$ \\
\hline $\begin{array}{l}\text { Creating an impulse about the } \\
\text { course }\end{array}$ & $71 \%$ & $\begin{array}{l}\text { Creating an impulse about the } \\
\text { course }\end{array}$ & $86 \%$ \\
\hline $\begin{array}{l}\text { Being persistent in the } \\
\text { memory }\end{array}$ & $100 \%$ & Being persistent in the memory & $100 \%$ \\
\hline Intensifying the interest & $86 \%$ & Intensifying the interest & $86 \%$ \\
\hline $\begin{array}{l}\text { Being relevant to the course } \\
\text { content and ILOs }\end{array}$ & $42 \%$ & $\begin{array}{l}\text { Being relevant to the course } \\
\text { content }\end{array}$ & $57 \%$ \\
\hline $\begin{array}{l}\text { M3. The benefits of self- } \\
\text { evaluation of interactive } \\
\text { presentations }\end{array}$ & $\%$ of students & $\begin{array}{l}\text { M4. The use of working in } \\
\text { teams in class }\end{array}$ & $\begin{array}{l}\% \text { of } \\
\text { students } \\
\text { agreeing }\end{array}$ \\
\hline $\begin{array}{l}\text { Creating an impulse about the } \\
\text { course }\end{array}$ & $86 \%$ & $\begin{array}{l}\text { Creating an impulse about the } \\
\text { course }\end{array}$ & $100 \%$ \\
\hline $\begin{array}{l}\text { Being persistent in the } \\
\text { memory }\end{array}$ & $100 \%$ & Being persistent in the memory & $86 \%$ \\
\hline Intensifying the interest & $86 \%$ & Intensifying the interest 7 & $100 \%$ \\
\hline $\begin{array}{l}\text { Being relevant to the course content and ILOs } \\
\text { content and ILOs }\end{array}$ & $\begin{array}{l}\text { Being relevant to the course } \\
\text { conts }\end{array}$ & $\begin{array}{l}\text { M6. The benefits of setting } \\
\text { mind maps }\end{array}$ & $\begin{array}{l}\% \text { of } \\
\text { students } \\
\text { agreeing }\end{array}$ \\
\hline $\begin{array}{l}\text { M5. The impact of analyzing } \\
\text { real- life case studies }\end{array}$ & $\%$ of students \\
agreeing & $86 \%$ & $\begin{array}{l}\text { Creating an impulse about the } \\
\text { course }\end{array}$ & $100 \%$ \\
\hline $\begin{array}{l}\text { Creating an impulse about the } \\
\text { course }\end{array}$ & $86 \%$ & Being persistent in the memory \\
\hline $\begin{array}{l}\text { Being persistent in the } \\
\text { memory }\end{array}$ & $100 \%$ & Being relevant to the course & $860 \%$ \\
\hline Intensifying the interest 7 \\
\hline Being relevant to the course & $100 \%$ & & $86 \%$ \\
\hline
\end{tabular}


Teaching with influence: an analysis of teaching methods used at the course of control systems

\begin{tabular}{|c|c|c|c|c|}
\hline $\begin{array}{l}\text { M1. The use of debates in this } \\
\text { course }\end{array}$ & \multicolumn{2}{|c|}{$\begin{array}{l}\% \text { of students } \\
\text { agreeing }\end{array}$} & $\begin{array}{l}\text { M2. The benefits of self- } \\
\text { learning presentations }\end{array}$ & $\begin{array}{l}\% \text { of } \\
\text { students } \\
\text { agreeing }\end{array}$ \\
\hline content and ILOs 7 & & & content and ILOs 7 & \\
\hline $\begin{array}{l}\text { M7. The impact of Simulating } \\
\text { wind movement and } \\
\text { suggesting solutions for } \\
\text { improving natural ventilation } \\
\text { in the students' own } \\
\text { apartments }\end{array}$ & \multicolumn{2}{|c|}{$\begin{array}{l}\% \text { of students } \\
\text { agreeing }\end{array}$} & & \\
\hline $\begin{array}{l}\text { Creating an impulse about the } \\
\text { course }\end{array}$ & 7 & $100 \%$ & & \\
\hline $\begin{array}{l}\text { Being persistent in the } \\
\text { memory }\end{array}$ & 6 & $100 \%$ & & \\
\hline Intensifying the interest 7 & 7 & $100 \%$ & & \\
\hline $\begin{array}{l}\text { Being relevant to the course } \\
\text { content and ILOs } 7\end{array}$ & 7 & $86 \%$ & & \\
\hline
\end{tabular}

Fig. 11. Illustrates the final results of the students' reactions to the C.S. teaching methods and the relevancy of each method to the overall ILOs of the course. Fig. 12 shows the results of the students' reactions to the impact of the C.S. course on their final graduation project, regarding its different phases.

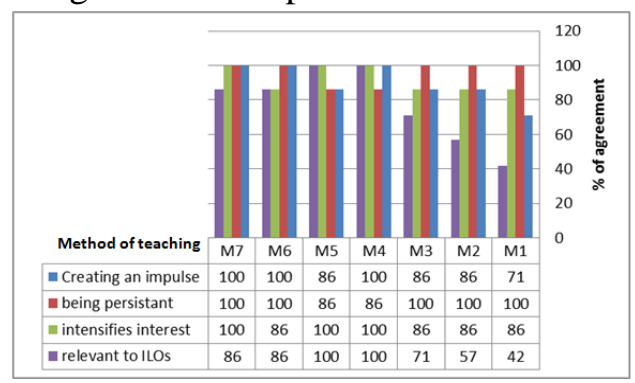

Fig. 11. The evaluation results of students' reactions towards different teaching methods

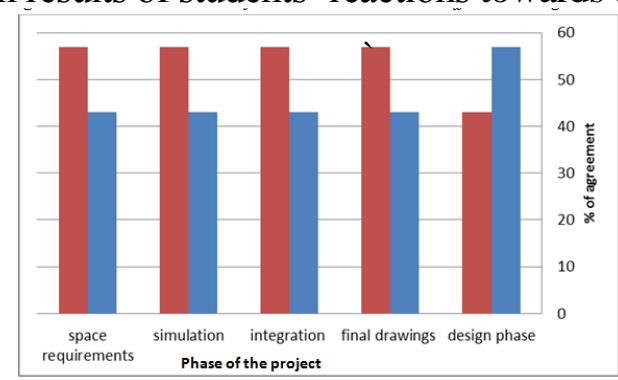

Fig. 12. The evaluation results of students' responses to the impact of the C.S. course on their final project throughout its different phases.

\section{Conclusions}

Based on the previously discussed results, it is obvious that the C.S. course had great influence on all the students who attended it.

- $86 \%$ of the course students agreed that the course affected their pattern of thinking concerning environmental issues, while the rest of them described its degree of impact as "much". 
- 57\% of the course students agreed that the course has affected their final project "much", while $43 \%$ believed it affected their project "very much".

The course has also affected the final grades of the students positively:

- $28 \%$ of the students got A grade in the 2013 semester, while no student got this grade in the 2011 semester for the same course.

- $72 \%$ of the students got a B grade (B+ and B) compared to $42 \%$ of 2011 students.

- None of the 2013 students got a $\mathrm{C}$ grade compared to $28 \%$ of the 2011 students.

Finally, it is recommended to continue examining the benefits of the teaching methods, techniques, tools and environment adopted in this course as some more years will be needed to get exact results.

\section{REFERENCES}

[1] Morteza K., Pakmehr B., et al. Another view to importance of teaching methods in curriculum: collaborative learning and students' critical thinking disposition - Procedia Social and Behavioral Sciences 46, 2012, pp. 3266 - 3270.

[2] Paul, R. How to Prepare Students for A Rapidly Changing World. Foundation for Critical Thinking, Santa Rosa, CA. 1995.

[3] Alfaro-Le Fevre, R. Critical Thinking and Clinical Judgment: A Practical Approach, $3^{\text {rd }}$ ed. Saunders, Philadelphia, 2004.

[4] Lyutykh, E., Practicing critical thinking in an educational psychology classroom, Journal of educational studies, 45, 2009, pp. 377-391.

[5] Bowell, T. \& Kemp, G. Critical Thinking: A Concise Guide, USA and Canada, (2005). (Chapter 1).

[6] Renaud, R. \& Murray, H. A comparison of a subject-specific and a general measure of critical thinking, Thinking Skills and Creativity, 3, 2008, pp. 85- 93.

[7] Anderson, LW. \& Krathwohl, DR. Taxonomy for learning, teaching, and assessing: a revision of bloom's taxonomy of educational objectives. New York: Longman, 2001.

[8] Jin, G., Bierma, T., Broadbear, J. Critical thinking among environmental health undergraduates and implications for the profession. Journal Environment Health, 67, 2004, pp.15-20.

[9] Tayfun Y., Arzu O., Nazan K. Experience of Traditional Teaching Methods in Architectural Design Education: "Mimesis Technique" - Procedia - Social and Behavioral Sciences 51, 2012, pp. 234 - 238. 


\section{التدريس عن طريق التأثير

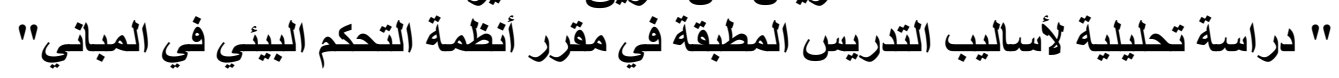 \\ الملخص العربى:}

يعتبر مقرر " انظمة التحكم البيئي في المباني" احدى المقررات الدراسية الاختيارية المقدمة لطلبة السنة

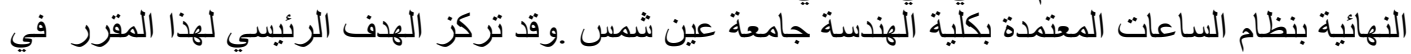

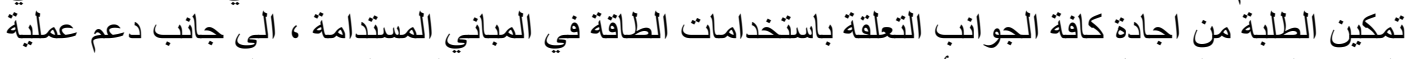

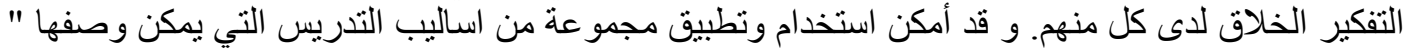

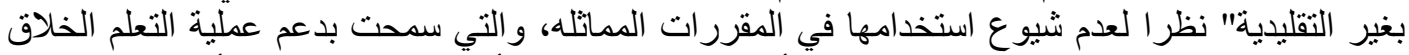

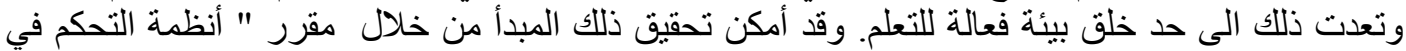

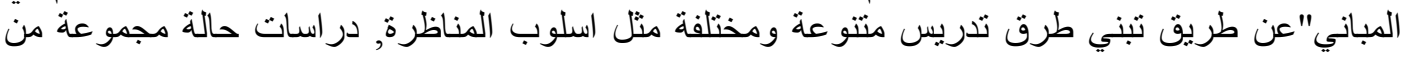

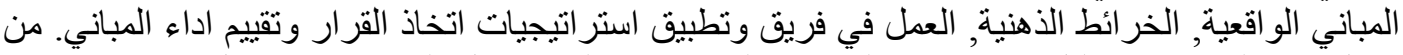

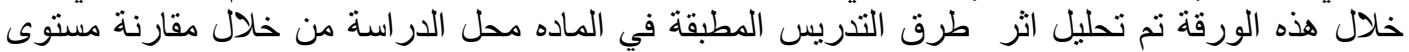

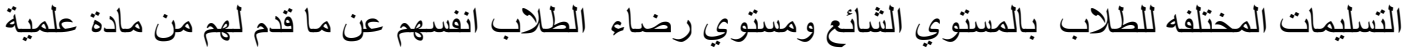

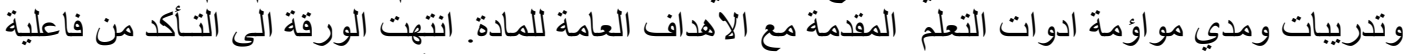

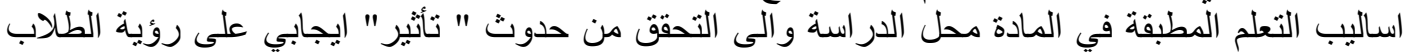

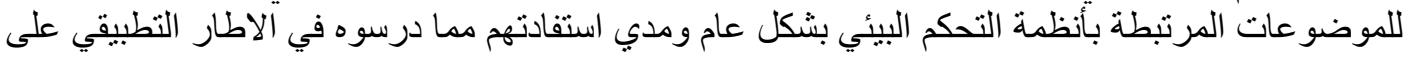
مشروع التخرج بشكل خاص. 